\title{
Extraction and Stability of Natural Dyes From The skin of Red Dragon Fruit
}

\author{
Ni Putu Bella Trisna Dewi ${ }^{1}$, Ni Made Ayu Suardani Singapurwa², I Gede Pasek Mangku ${ }^{3}$ \\ Department of Food Science and Technology Faculty of Agricultural, Warmadewa University, \\ Denpasar-Bali, Indonesia \\ ${ }^{1}$ Email: bellatrisnadewi@gmail.com \\ ${ }^{2}$ E-mail: a.suardani@ymail.com
}

\begin{abstract}
Dragon fruit skin contains anthocyanin dyes which are quite high. Anthocyanins are dyes that give red color and can be used as natural dyes for food. This study aims to determine the ratio of the $10 \%$ citric acid solution with the time of maceration to obtain the highest anthocyanin levels and to determine the stability of the red dragon fruit peel extract. The research design used was a factorial completely randomized design (CRD) with two factors, namely the ratio of red dragon fruit peel pulp with $10 \%$ citric acid solvent consisting of three levels: 1: 3; 1: 6; 1: 9. The second factor is the length of maceration of the red dragon fruit skin which consists of three levels: 3 days; 3.5 days; 4 days. Analysis of red dragon fruit peel extract includes yield, anthocyanin levels, $\mathrm{pH}$ value, color intensity, and stability test. The best treatment of red dragon fruit peel extraction was obtained in the sample ratio of 10\% citric acid solution (1:3) and the duration of maceration for 4 days with a yield of 22.92\%; $\mathrm{pH}$ value of 1.84; anthocyanin levels of $52.27 \mathrm{mg} / \mathrm{L}$; L * color intensity of 16.54; color intensity $a *$ of 75.57; color intensity $b *$ was 9.63 and the best anthocyanin dye stability test was obtained at a pH of 3 and a temperature of $7^{\circ} \mathrm{C}$.
\end{abstract}

Keyword: Extraction, stability, anthocyanin, red dragon fruit skin.

\section{Introduction}

Indonesia is a tropical country that is rich in fruits. Various fruits can be cultivated well and thrive, one of which is red dragon fruit. However, the part of red dragon fruit that is often used is the flesh, while the skin of the dragon fruit is often thrown into waste. Even though dragon fruit has a fairly thick skin, which is between 30-35\%. Dragon fruit peel contains high enough natural anthocyanin dyes. Anthocyanins are dyes that have a role to give red color and have the potential to become natural dyes for food and can be used as an alternative to synthetic dyes that are safer for health [1].

The effort to utilize the red dragon fruit peel is by extracting anthocyanin pigments using the maceration extraction method. Anthocyanins are classified as pigments called flavonoids that can dissolve in polar solvents [2]. Acidic conditions also affect the extraction yield. The more acidic, the more anthocyanin pigments are in the form of colored flavilium or oxonium cations and the absorbance measurement will show that the number of anthocyanins is getting bigger [3]. The acid condition also causes more and more vacuole cell walls to break so that more anthocyanin pigments are extracted. The type of acid used is citric acid to extract the skin of red dragon fruit. Citric acid has advantages over other acids, namely odorless, easy to find, and relatively inexpensive and the use of distilled water as a solvent will produce an extract without alcohol content so that further processing towards food will be more acceptable to consumers. Processing of red dragon fruit skin This is one way of handling dragon fruit peel waste so that it can increase the economic value of dragon fruit peel and can be used as an alternative to synthetic dyes that are safer for health and contain high natural anthocyanin dyes. 


\section{Material and Methods}

This research was conducted at the Laboratory of Processing, Faculty of Agriculture, Warmadewa University, and Analysis Laboratory of the Faculty of Agriculture, Warmadewa University. This research was conducted from May 2020 - July 2020.

The tools used are rotary vacuum evaporator, blender, knife, analytical balance, Uv-Vis spectrophotometer, glass funnel, beaker glass, Erlenmeyer, measuring cup, test tube, measuring flask, spatula, measuring pipette, fine filter paper, glass bottle, ball suction, dropper, $\mathrm{pH}$ meter. The materials used were red dragon fruit peel, distilled water, $10 \%$ citric acid, $\mathrm{pH} 1$ buffer, $\mathrm{pH} 4.5$ buffer, and $\mathrm{NaOH}$.

The research design used was a completely randomized design (CRD) factorial pattern with 2 factors, namely 2 (two), namely: Factor I ratio of $10 \%$ citric acid solution consisting of $1: 3 ; 1: 6 ; 1$ : 9. The second factor is the length of maceration which consists of 3 days, 3.5 days, 4 days. Each treatment was repeated 3 times to obtain 27 experimental units. The data from the observations were analyzed using analysis of variance or ANOVA (Analysis of Variance) with a completely randomized design method followed by DMRT (Duncan Multiple Range Test) with a confidence interval of $5 \%$.

The extraction process in this study was carried out using distilled water and $10 \%$ citric acid using the maceration method. The red dragon fruit peel extract is made in several stages, namely, the red dragon fruit peel is sorted according to uniform size and color, then followed by washing until all the dirt stuck to the dragon fruit skin is gone, then the skin is cut into $1 \mathrm{x} 1 \mathrm{~cm}$ size and then blended. A total of $90 \mathrm{~mL}$ of dragon fruit peel samples were weighed and then added with a 10\% citric acid solution with various concentrations of 1: $3,1: 6$, and 1: 9. The next step is maceration extraction which is done by soaking the skin of the red dragon fruit for 3 days, 3.5 days, and 4 days. The extraction results obtained are then filtered and then concentrated using a rotary vacuum evaporator at a temperature of $50^{\circ} \mathrm{C}$ at a speed of $80 \mathrm{rpm}$ to reach the desired thickness. The concentrated extract was then calculated the amount of yield obtained, analyzed the anthocyanin content contained using a UV-Visible spectrophotometer, the color intensity value with a colorimeter, and stability tests against $\mathrm{pH}$ and temperature.

\section{Result and Discussion}

\subsection{Yield}

Based on the analysis of variance, it can be seen that the treatment ratio of $10 \%$ citric acid solvent, maceration time treatment, and the interaction between the two to the yield value is very significant $(\mathrm{p}<0.01)$. The yield of red dragon fruit peel extract with a ratio of $10 \%$ citric acid solution with a long maceration time can be seen in Table 1.

In Table 1 it shows that the highest average yield value of $60.91 \%$ is produced by the sample with the red dragon fruit peel extract sample, the ratio of $10 \%$ citric acid solvent (1: 9) with 4 days of maceration time and has a very significant effect with the ratio of the solvent. citric acid $10 \%$ (1: 3 ) and (1: 6) and not significantly different with the ratio of maceration length of 3 days and 3.5 days. The more the ratio of $10 \%$ citric acid solution is used, the tendency of the $\mathrm{pH}$ of the solution will decrease. This acidic condition causes more and more vacuole walls to break so that the more anthocyanin pigments are extracted and the longer the maceration time required for the extraction of red dragon fruit skin, the more anthocyanin pigments are extracted [4]. Meanwhile, the longer the 
maceration is used, the more dissolved compounds will also increase. The more compounds dissolved, the more yield is obtained [5]. The effect of $10 \%$ citric acid solution with maceration time on the yield of red dragon fruit peel extract as shown in Figure 1 shows that the more the ratio of the $10 \%$ citric acid solution and the longer the maceration time, the more yield will be produced.

Table 1

Yield (\%) Red Dragon Fruit Skin Extract with 10\% Citric Acid Solvent Comparison and Maceration Time

\begin{tabular}{cccc}
\hline Treatment & \multicolumn{3}{c}{ Maceration Time } \\
\cline { 2 - 4 } Solvent & 3 Day & 3.5 Day & 4 Day \\
\hline $1: 3$ & $18.20 \mathrm{c}$ & $20.49 \mathrm{~b}$ & $22.92 \mathrm{a}$ \\
& $(\mathrm{c})$ & $(\mathrm{c})$ & $(\mathrm{c})$ \\
$1: 6$ & $35.35 \mathrm{c}$ & $36.19 \mathrm{~b}$ & $37.02 \mathrm{a}$ \\
& $(\mathrm{b})$ & $(\mathrm{b})$ & $(\mathrm{b})$ \\
$1: 9$ & $56.87 \mathrm{c}$ & $57.44 \mathrm{~b}$ & $60.91 \mathrm{a}$ \\
& $(\mathrm{a})$ & (a) & (a) \\
\hline
\end{tabular}

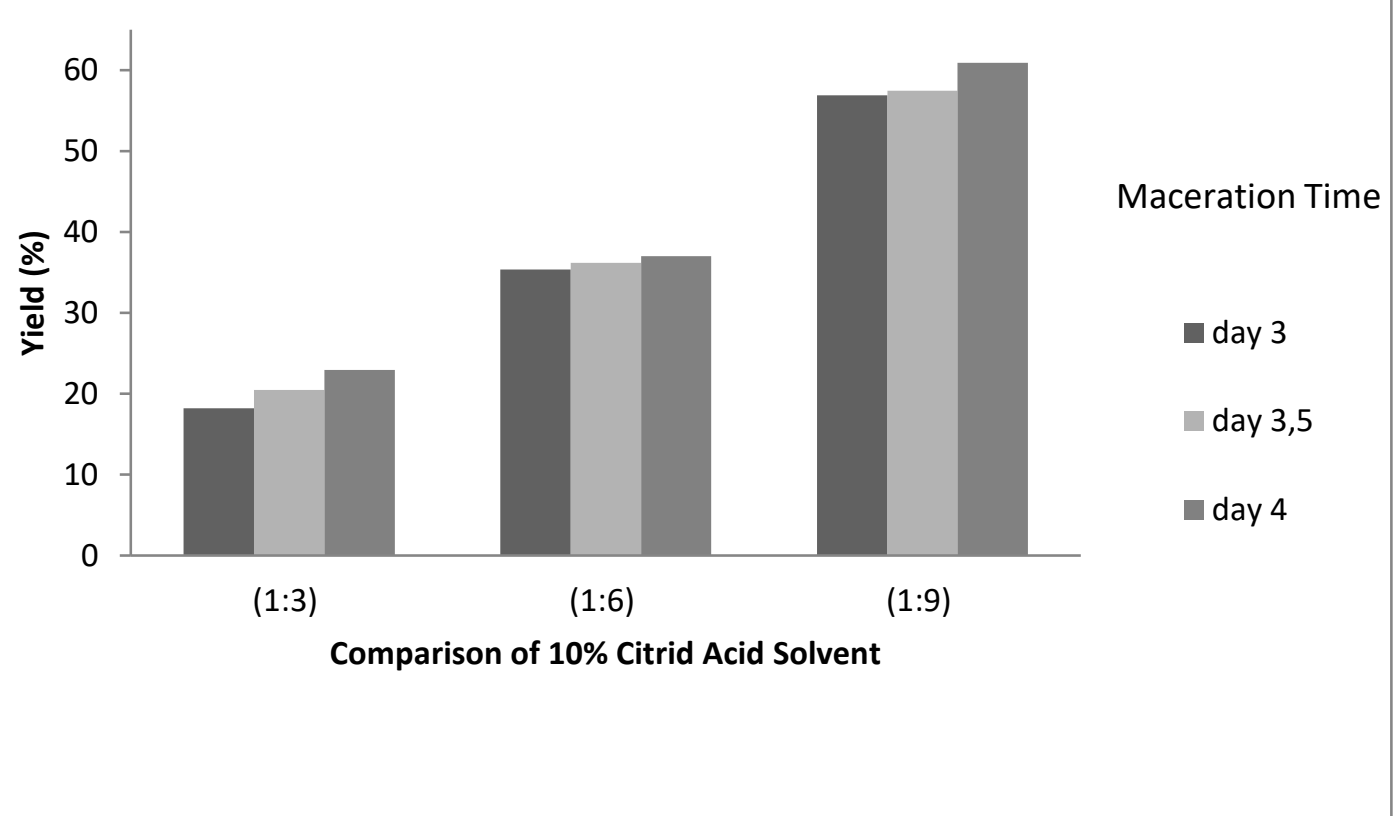

Figure 1. Graph of the Interaction Value of Red Dragon Fruit Skin Extract Rendement Comparison of $10 \%$ Citric Acid Solvent and Maceration Time

\section{2 pH Value}

Based on the analysis of variance, it can be seen that the comparative treatment between $10 \%$ citric acid solvent and maceration time has a very significant effect $(\mathrm{p}<0.01)$ while the interaction between the two treatments has no significant effect ( $>>0.05)$ on the value. The $\mathrm{pH}$ of the dragon fruit peel extract was obtained. The $\mathrm{pH}$ value from the extraction of red dragon fruit skin can be seen in Table 2. 
Table 2

The $\mathrm{pH}$ value of the Extraction of Red Dragon Fruit Skin with a Comparison of $10 \%$ Citric Acid Solvent and the Time of Maceration

\begin{tabular}{ccccc}
\hline Treatment & 3 Day & 3.5 Day & 4 Day & Average \\
\hline $1: 3$ & 1.86 & 1.85 & 1.84 & $1.85 \mathrm{a}$ \\
$1: 6$ & 1.64 & 1.64 & 1.63 & $1.64 \mathrm{~b}$ \\
$1: 9$ & 1.60 & 1.58 & 1.57 & $1.59 \mathrm{c}$ \\
\hline Average & $1.70 \mathrm{a}$ & $1.69 \mathrm{ab}$ & $1.68 \mathrm{~b}$ & \\
\hline
\end{tabular}

In Table 2, it is shown that the lowest $\mathrm{pH}$ average value of 1.57 was produced by a sample with a treatment ratio of $10 \%$ citric acid solution (1: 9) and 4 days of maceration and this treatment was significantly different from the ratio of $10 \%$ citric acid solvent (1:3) and (1: 6). The effect of adding solvent to the $\mathrm{pH}$ value of the red dragon fruit peel extract is shown in Figure 2 and the effect of maceration time on the $\mathrm{pH}$ value is shown in Figure 3. In Figure 2, it can be seen that the higher the addition of the citric acid solution, the lower the $\mathrm{pH}$ value will be. The low $\mathrm{pH}$ value of the red dragon fruit peel extract is needed to increase the stability of the anthocyanin pigments contained in the extract so that the color becomes brighter. The longer maceration time also results in the red dragon fruit peel extract having a low $\mathrm{pH}$ value. The lower the $\mathrm{pH}$ value, the more stable the anthocyanin will be. Following the opinion of [6] that the addition of citric acid by $5 \%$ can increase the yield of anthocyanin extracts by $15 \%$ and reduce the $\mathrm{pH}$ so that the anthocyanins in the ingredients are more stable.

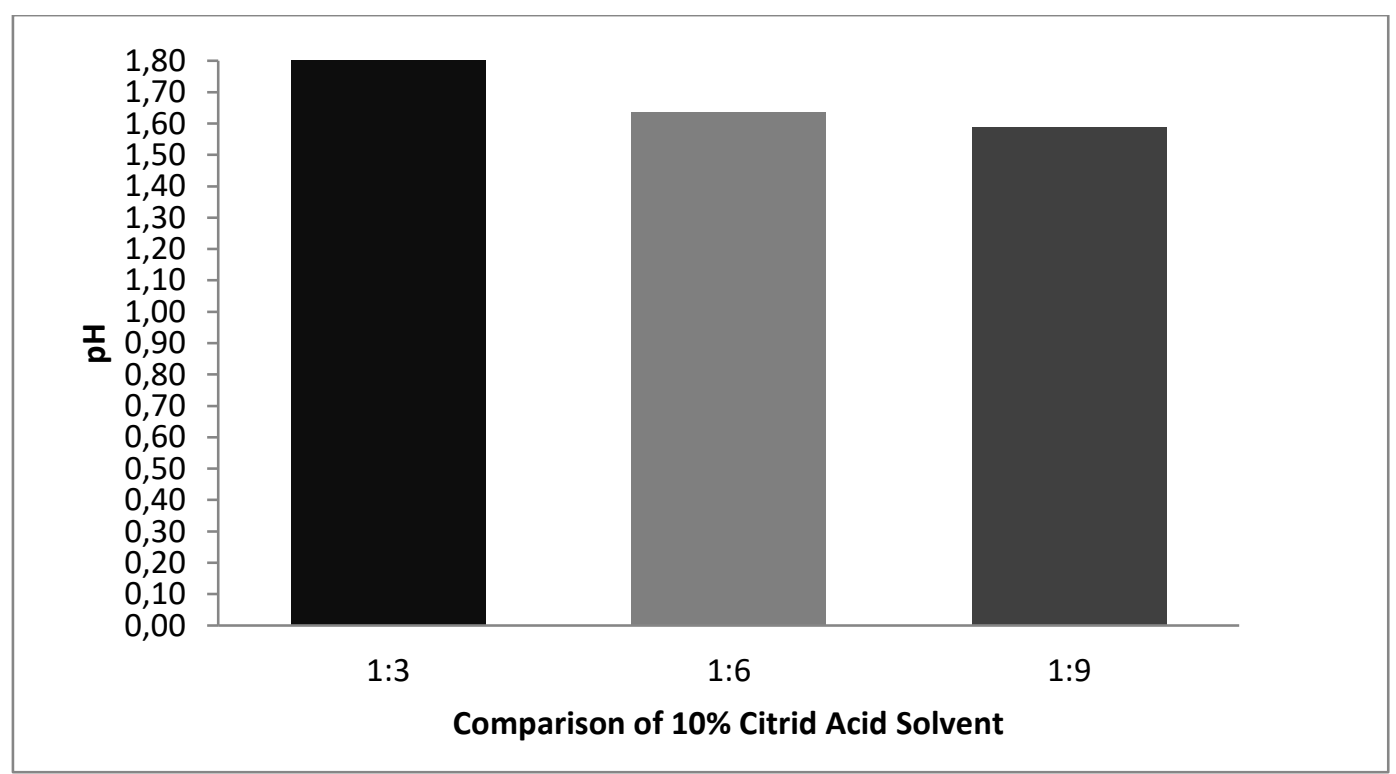

Figure 2. Graph of Comparative Effect of $10 \%$ Citric Acid Solvent on $\mathrm{pH}$ 


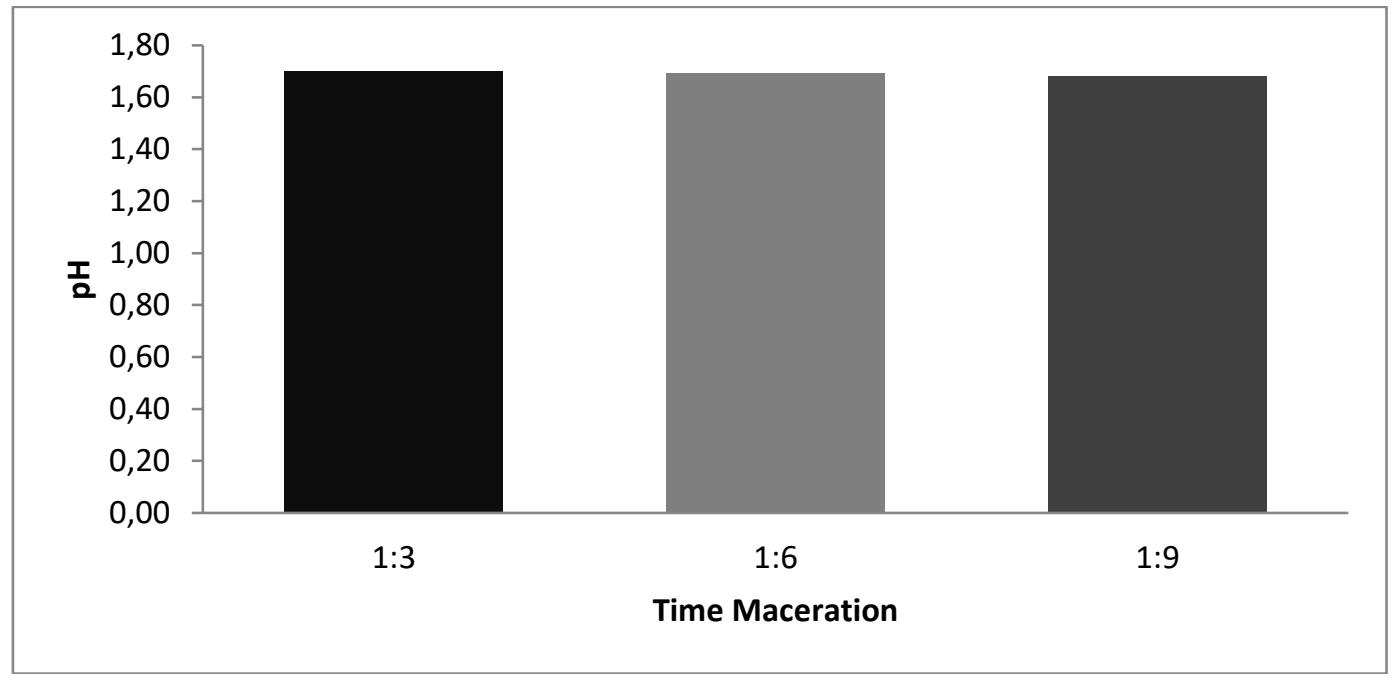

Figure 3. Graph of the Effect of Maceration Time on $\mathrm{pH}$

\subsection{Anthocyanin Levels}

Based on the analysis of variance, it can be seen that the treatment ratio of $10 \%$ citric acid solvent and maceration time to the anthocyanin levels of the red dragon fruit peel extract has a significant effect $(\mathrm{p}<0.01)$. Anthocyanin levels from red dragon fruit peel extract with a comparison of $10 \%$ citric acid solvent and maceration time can be seen in Table 3 .

Table 3

Anthocyanin levels of Red Dragon Fruit Skin with a comparison of $10 \%$ citric acid solvent and maceration time

\begin{tabular}{lccc}
\hline Treatment & \multicolumn{3}{c}{ Maceration Time } \\
\hline Solvent & Day 3 & Day 3.5 & Day 4 \\
\hline $1: 3$ & $48.60 \mathrm{c}$ & $50.10 \mathrm{~b}$ & $52.27 \mathrm{a}$ \\
& $(\mathrm{a})$ & $(\mathrm{a})$ & (a) \\
$1: 6$ & $35.07 \mathrm{c}$ & $40.317 \mathrm{~b}$ & $44.42 \mathrm{a}$ \\
& (b) & $(\mathrm{b})$ & $(\mathrm{b})$ \\
$1: 9$ & $28.70 \mathrm{c}$ & $30.28 \mathrm{~b}$ & $33.75 \mathrm{a}$ \\
& (c) & (c) & (c) \\
\hline
\end{tabular}

Table 3 shows that the more the ratio of the $10 \%$ citric acid solvent used to extract the red dragon fruit peel the longer it will take to obtain the red dragon fruit peel extract using a rotary vacuum evaporator so that the absorbance value of the red dragon fruit peel extract is getting higher. time will decrease because it is not stable for continuous heating. This decrease in absorbance is due to damage to the pigment chromophore groups which causes color damage. According to [7], stated that the decrease in color stability due to temperature was thought to be caused by the decomposition of anthocyanins from the form of aglycones to chalcone (colorless). The lower the absorbance value, the smaller the anthocyanin levels obtained. Meanwhile, the longer the maceration time, the more acidic the red dragon fruit peel extract is, which causes the anthocyanin pigment to be more stable in the 4-day maceration time. The interaction of anthocyanin levels from the red dragon fruit peel extract, the ratio of $10 \%$ citric acid solution to the maceration time can be seen in Figure 4. 


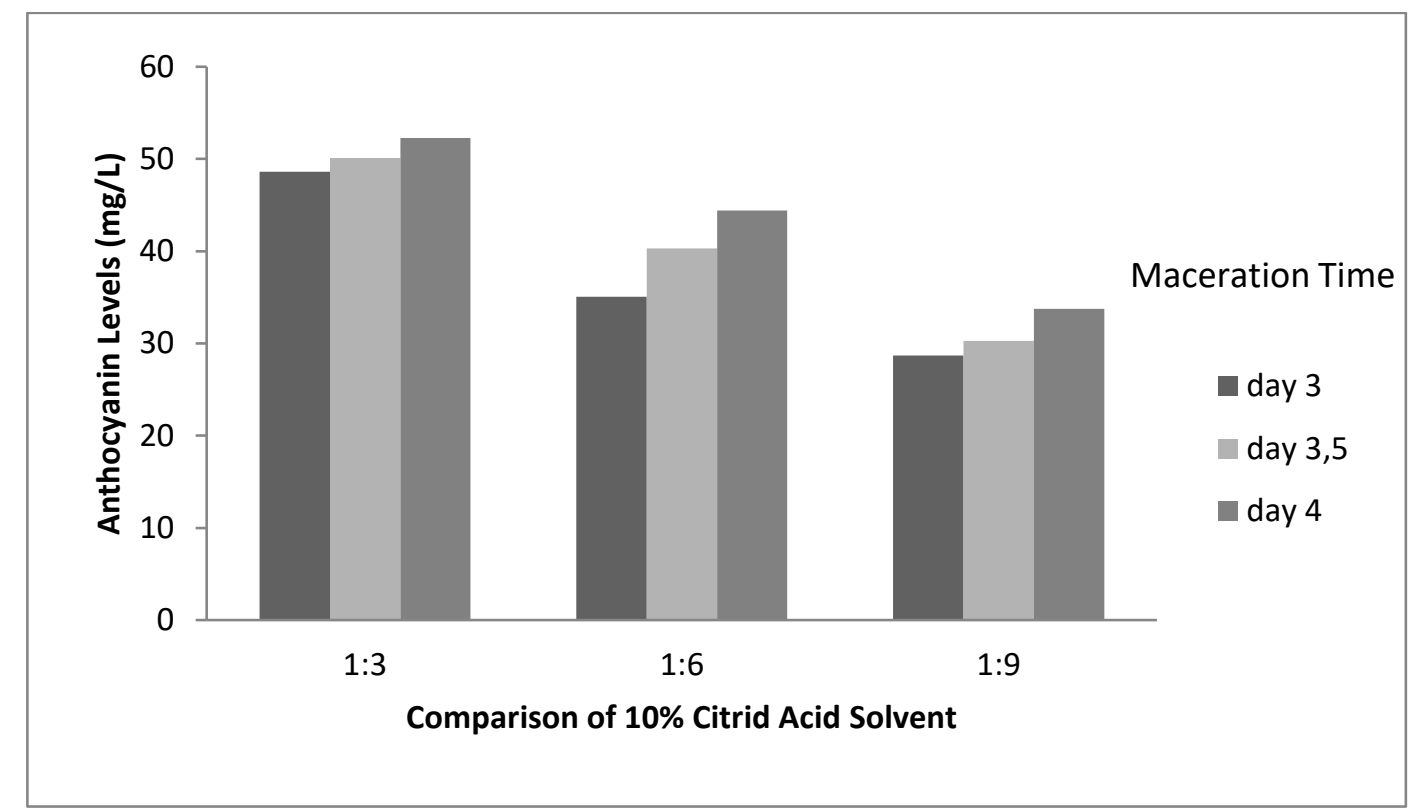

Figure 4. Interaction Graph Anthocyanin Levels from Red Dragon Fruit Skin Extract Comparison of $10 \%$ Citric Acid Solvent and Maceration Time

\subsection{Color Intensity}

\subsubsection{Color Intensity L Value * (Brightness Level)}

Based on the analysis of variance, it can be seen that the treatment ratio of $10 \%$ citric acid solvent, maceration time, and the interaction between the two treatments has a very significant effect $(\mathrm{p}<0.01)$ on the color intensity of $\mathrm{L} *$ can be seen in Table 4 .

Table 4

Red Dragon Fruit Skin Extract Color Intensity L * Value

\begin{tabular}{cccc}
\hline Treatment & \multicolumn{3}{c}{ Maceration Time } \\
\hline Solvent & day 3 & day 3.5 & day 4 \\
\hline $1: 3$ & $18.47 \mathrm{a}$ & $17.44 \mathrm{~b}$ & $16.54 \mathrm{c}$ \\
& (c) & (c) & (c) \\
$1: 6$ & $22.77 \mathrm{a}$ & $29.21 \mathrm{c}$ & $23.74 \mathrm{~b}$ \\
& (b) & (b) & (b) \\
$1: 9$ & $26.08 \mathrm{c}$ & $34.63 \mathrm{~b}$ & $36.18 \mathrm{a}$ \\
& (a) & (a) & (a) \\
\hline
\end{tabular}

In Table 4. the color intensity of the $\mathrm{L} *$ value of red dragon fruit peel extract obtained is the lowest in the sample ratio of $10 \%$ citric acid solvent with 4 days of maceration, which is 16,54 and the highest color intensity value in the sample comparison of $10 \%$ citric acid solution with a 4 day maceration time of 36,18 . This is because the anthocyanin levels contained in the red dragon fruit peel extract are the highest so that the resulting brightness level is lower (dark). The results of the research by [8] show that the more pigment that is extracted causes the color of the extract to be darker and darker so that the brightness value decreases. The interaction of the color intensity of the $\mathrm{L} *$ value of the red dragon fruit peel extract can be seen in Figure 5. 


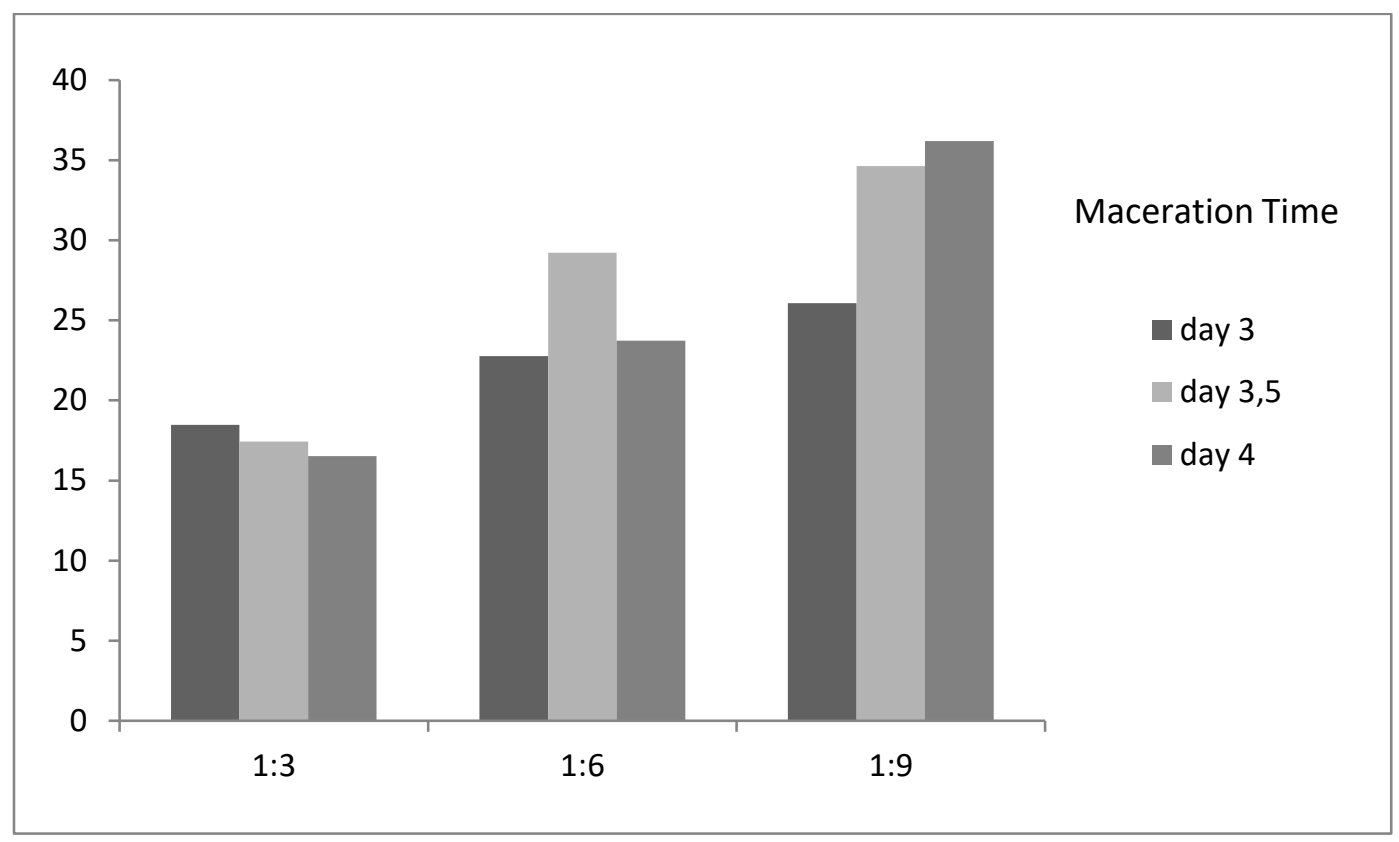

Figure 5. L * Color Intensity Interaction Graph

\subsubsection{Color Intensity Value a * (Redness Level)}

Based on the analysis of variance, it can be seen that the treatment ratio of $10 \%$ citric acid solvent, the length of maceration time, and the interaction between the two red treatments had a significant effect $(\mathrm{P}<0.01)$ on the color intensity a $*$ of the red dragon fruit peel extract. The color intensity of the red dragon fruit peel extract at the * value can be seen in Table 5 .

Table 5

Red Dragon Fruit Skin Extract Color Intensity Value a *

\begin{tabular}{lccc}
\hline Treatment & \multicolumn{3}{c}{ Maceration Time } \\
\hline Solvent & day 3 & day 3.5 & day 4 \\
\hline $1: 3$ & $72.53 \mathrm{~b}$ & $70.28 \mathrm{c}$ & $75.57 \mathrm{a}$ \\
& (a) & (a) & (a) \\
$1: 6$ & $60.47 \mathrm{~b}$ & $54.53 \mathrm{c}$ & $67.09 \mathrm{a}$ \\
& $(\mathrm{b})$ & $(\mathrm{b})$ & $(\mathrm{b})$ \\
$1: 9$ & $55.34 \mathrm{a}$ & $51.08 \mathrm{~b}$ & $49.18 \mathrm{c}$ \\
& $(\mathrm{c})$ & $(\mathrm{c})$ & $(\mathrm{c})$ \\
\hline
\end{tabular}

Table 5 shows that in samples with a citric acid solvent ratio of $10 \%$ (1: 3) and a maceration time of 4 days the highest a $*$ color intensity is 75.57 and the lowest a $*$ color intensity value in the sample ratio of $10 \%$ citric acid solvent (1: 9) with a 4-day maceration length of 49.18. The color intensity value $\mathrm{a} *$ is directly proportional to the anthocyanin content. The sample with the highest a * color intensity value also had the highest anthocyanin content, namely 52.27 in the sample with a citric acid solvent ratio of $10 \%(1: 3)$ with a maceration time of 4 days (Table 3$)$. This is by [9[ that the higher the red color intensity, the higher the anthocyanin levels. The interaction of a $*$ color intensity can be seen in Figure 6. 


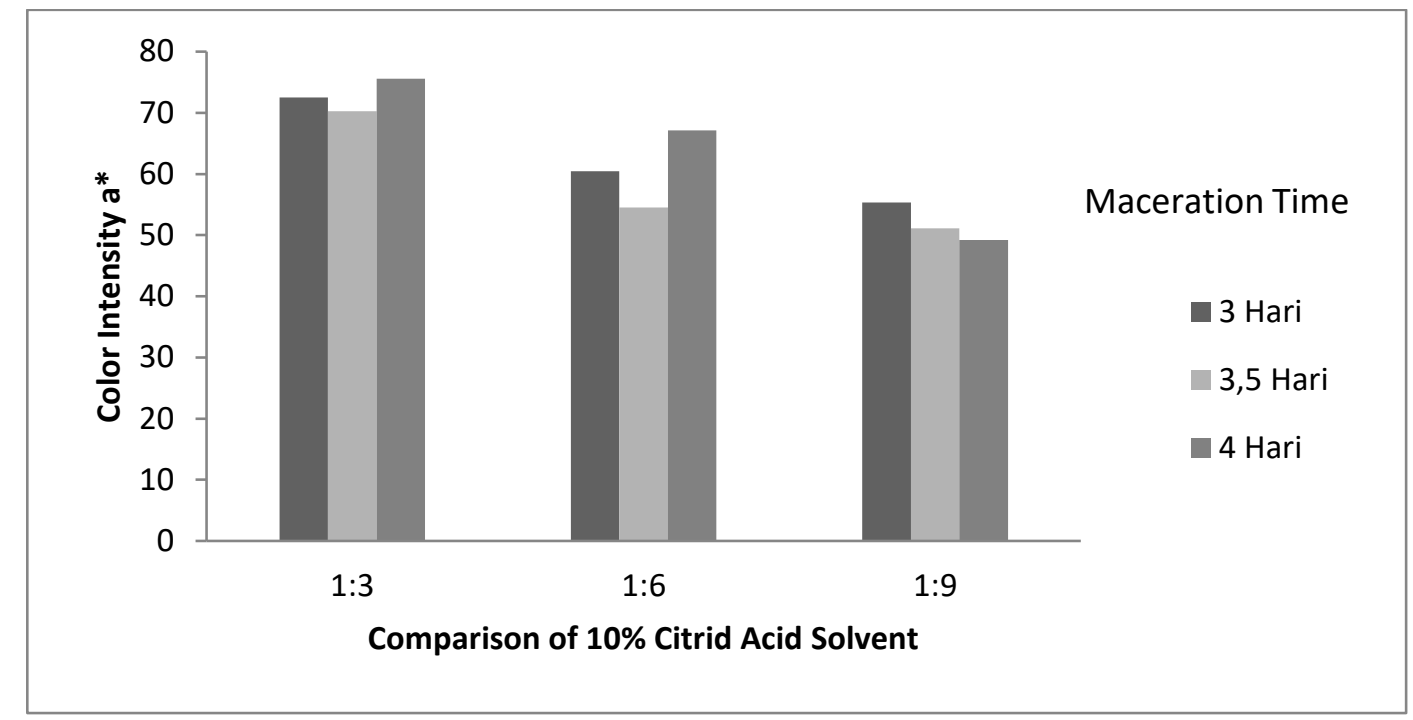

Figure 6. Color Intensity Interaction Graph a *

\subsubsection{Color Intensity Value $b *$ (Yellowish Level)}

Based on the analysis of variance, it can be seen that the treatment ratio of $10 \%$ citric acid solvent, the length of maceration time, and the interaction between the two red treatments have a significant effect $(\mathrm{p}<0.01)$ on the intensity of the color $\mathrm{b} *$ of the red dragon fruit peel extract. The color intensity of the red dragon fruit peel extract at the $b *$ value can be seen in Table 6 .

Table 6

Red Dragon Fruit Skin Extract Color Intensity b Value *

\begin{tabular}{cccc}
\hline Treatment & \multicolumn{3}{c}{ Maceration Time } \\
\hline Solvent & day 3 & day 3.5 & day 4 \\
\hline $1: 3$ & $11.93 \mathrm{~b}$ & $15.69 \mathrm{a}$ & $9.63 \mathrm{c}$ \\
& (c) & (c) & (c) \\
$1: 6$ & $24.86 \mathrm{~b}$ & $27.85 \mathrm{a}$ & $18.88 \mathrm{c}$ \\
& $(\mathrm{a})$ & $(\mathrm{b})$ & $(\mathrm{b})$ \\
$1: 9$ & $22.55 \mathrm{c}$ & $32.87 \mathrm{~b}$ & $34.68 \mathrm{a}$ \\
& (b) & (a) & (a) \\
\hline
\end{tabular}

Table 6 shows that in samples with a citric acid solvent ratio of $10 \%(1: 3)$ and a maceration time of 4-days the lowest $b *$ color intensity was 9.63 and the highest intensity value was obtained in samples with a citric acid solvent ratio of 10\%. (1: 9) with a 4-day maceration length of 34.68. These results indicate that the lower the color intensity $b^{*}$, the bluer it will be. This is in line with [4], which states that anthocyanins include flavonoid pigments that are red to blue. The interaction of the color intensity of $\mathrm{b} *$ red dragon fruit peel extract, the ratio of distilled water, and citric acid with the maceration time can be seen in Figure 7. 


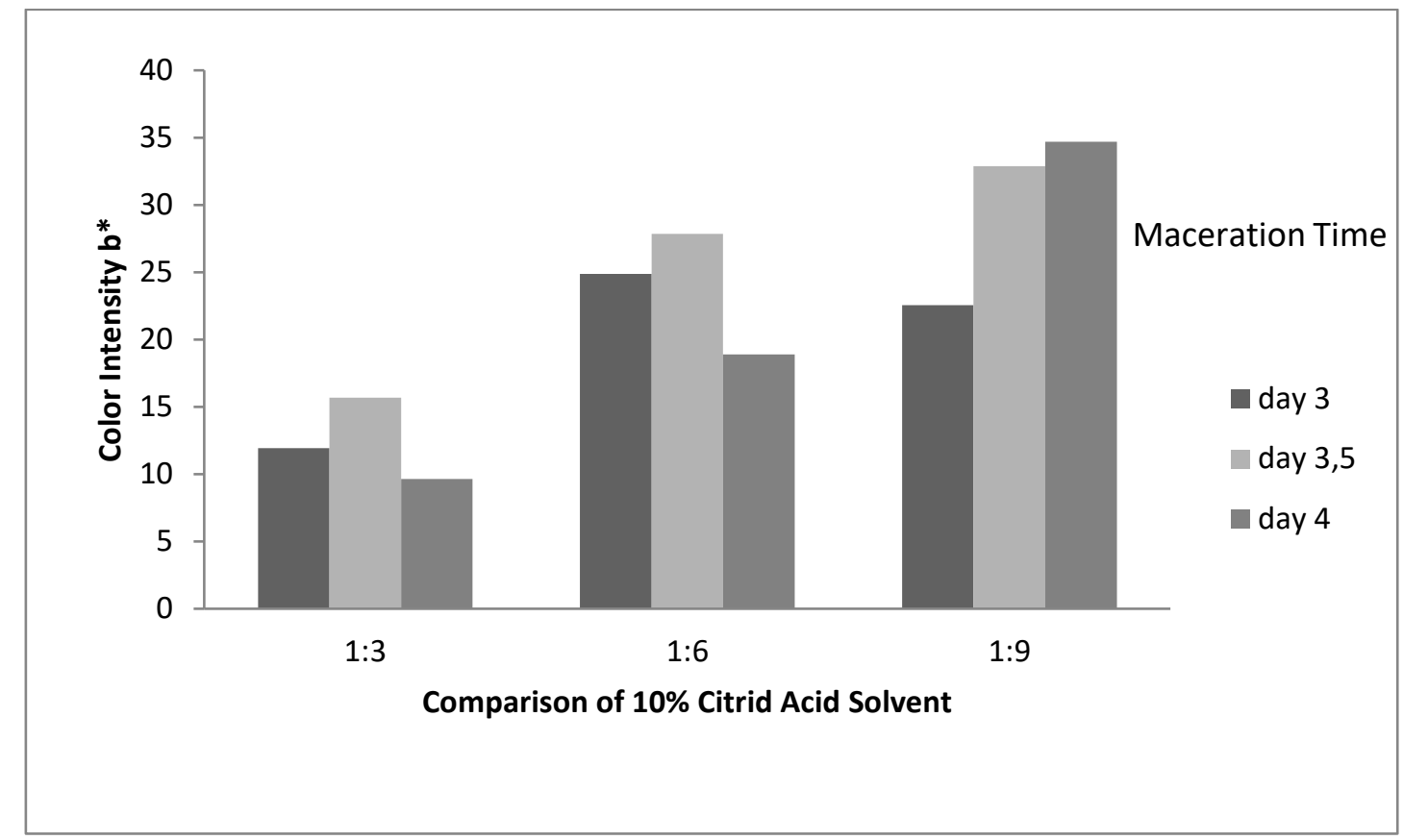

Figure 7. Color Intensity Interaction Graph b *

\subsection{Stability Test}

\subsubsection{Effect of pH on Anthocyanin Stability}

The degree of acidity $(\mathrm{pH})$ is one of the factors that affect the stability of the red dragon fruit skin dye. According to [10], the lower the $\mathrm{pH}$ value, the more red and stable the color of the concentrate is, or if the $\mathrm{pH}$ is closer to one, the more stable the color. The stability test of the red dragon fruit peel extract against $\mathrm{pH}$ can be seen in Table 7 and the graph of the stability test of the red dragon fruit peel extract against $\mathrm{pH}$ can be seen in Figure 8.

Table 7

Stability Test of Red Dragon Fruit Skin Extract against $\mathrm{pH}$

\begin{tabular}{lcccc}
\hline Sample & \multicolumn{4}{c}{ Stability Test } \\
\cline { 2 - 5 } & $\mathrm{pH} \mathrm{3}$ & $\mathrm{pH} \mathrm{4}$ & $\mathrm{pH} \mathrm{5}$ & $\mathrm{pH} \mathrm{6}$ \\
\hline (1:3) Maceration Day 3 & 0.943 & 0.784 & 0.537 & 0.433 \\
(1:6) Maceration Day 3 & 0.574 & 0.465 & 0.409 & 0.378 \\
(1:9) Maceration Day 3 & 0.432 & 0.347 & 0.302 & 0.217 \\
(1:3) Maceration Day 3.5 & 1.224 & 0.898 & 0.703 & 0.527 \\
(1:6) Maceration Day 3.5 & 0.712 & 0.496 & 0.440 & 0.385 \\
(1:9) Maceration Day 3.5 & 0.588 & 0.387 & 0.317 & 0.287 \\
(1:3) Maceration Day 4 & 1.728 & 0.993 & 0.875 & 0.637 \\
(1:6) Maceration Day 4 & 1.355 & 0.677 & 0.562 & 0.478 \\
(1:9) Maceration Day 4 & 0.834 & 0.483 & 0.367 & 0.333 \\
\hline
\end{tabular}




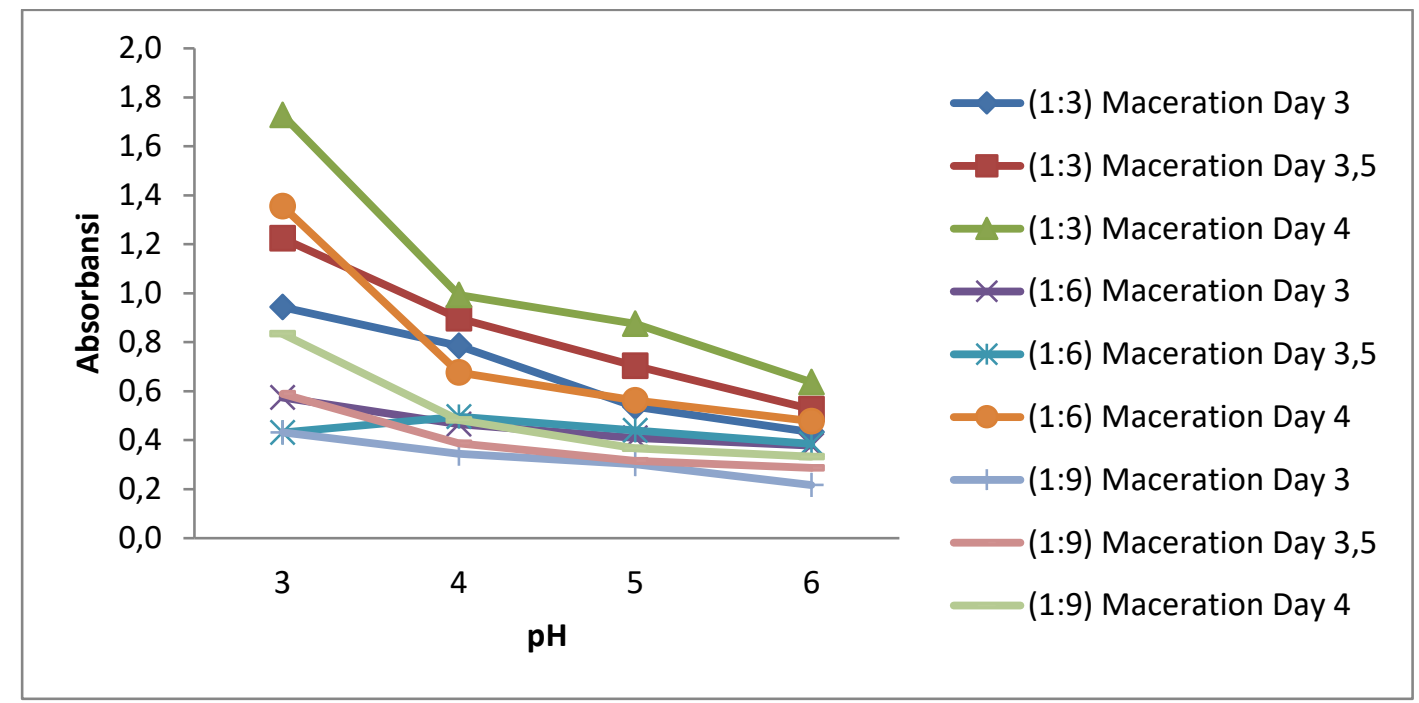

Figure 8. Stability Test Graph of Red Dragon Fruit Skin Extract against pH

Based on Figure 8, it can be seen that as $\mathrm{pH}$ increases, the absorbance decreases. At a higher $\mathrm{pH}$ concentration, the anthocyanin color fades because of the red flavilium cation hydrates into colorless carbinol. This causes anthocyanins to break down easily at high $\mathrm{pH}$ conditions [10]. The stability test of dragon fruit peel extract was most stable at $\mathrm{pH}$ 3. Based on the analysis of variance, it can be seen that the ratio of $10 \%$ citric acid solvent, maceration time, and the interaction between the two treatments had a very significant effect $(\mathrm{p}<0.01)$. The stability test at $\mathrm{pH} 3$ can be seen in Table 8 .

Table 8

Stability Test at $\mathrm{pH} 3$

\begin{tabular}{lccc}
\hline Treatment & \multicolumn{3}{c}{ Maceration Time } \\
\hline Solvent & day 3 & day 3.5 & day 4 \\
\hline $1: 3$ & $0.943 \mathrm{c}$ & $1.224 \mathrm{~b}$ & $1.728 \mathrm{a}$ \\
& (a) & $(\mathrm{a})$ & (a) \\
$1: 6$ & $0.574 \mathrm{c}$ & $0.712 \mathrm{~b}$ & $1.358 \mathrm{a}$ \\
& (b) & $(\mathrm{b})$ & (b) \\
$1: 9$ & $0.432 \mathrm{c}$ & $0.589 \mathrm{~b}$ & $0.834 \mathrm{a}$ \\
& (c) & (c) & (c) \\
\hline
\end{tabular}

Based on Table 8, it can be seen that the treatment ratio of $10 \%$ citric acid solvent (1:3) and 4 days of maceration time resulted in the highest absorbance value of 1.728. This is also comparable to the highest anthocyanin levels obtained in the same treatment at a solvent ratio of $10 \%$ citric acid (1: 3 ) and 4 days of maceration time (Table 3).

\subsubsection{Effect of Temperature on Anthocyanin Stability}

Environmental temperature is a factor that determines the stability of anthocyanins. The higher the heating temperature, the lower the absorbance, or color stability so that the red color will decrease. The red extract obtained will be reduced [10]. The stability test of the red dragon fruit peel extract against temperature can be seen in Table 9 and the graph of the stability test of dragon fruit skinny to temperature can be seen in Figure 9. 
Table 9

Stability Test of Red Dragon Fruit Skin Extract against Temperature

\begin{tabular}{lccc}
\hline Sample & \multicolumn{3}{c}{ Stability Test } \\
\cline { 2 - 4 } & $7^{\circ} \mathrm{C}$ & $27^{\circ} \mathrm{C}$ & $80^{\circ} \mathrm{C}$ \\
\hline (1:3) Maceration Day 3 & 2.600 & 2.537 & 2.499 \\
(1:6) Maceration Day 3 & 2.601 & 2.526 & 2.446 \\
(1:9) Maceration Day 3 & 2.589 & 2.487 & 2.332 \\
(1:3) Maceration Day 3.5 & 2.648 & 2.547 & 2.503 \\
(1:6) Maceration Day 3.5 & 2.634 & 2.535 & 2.491 \\
(1:9) Maceration Day 3.5 & 2.611 & 2.483 & 2.415 \\
(1:3) Maceration Day 4 & 2.689 & 2.593 & 2,570 \\
(1:6) Maceration Day 4 & 2,671 & 2,580 & 2,521 \\
(1:9) Maceration Day 4 & 2,658 & 2,499 & 2,422 \\
\hline
\end{tabular}

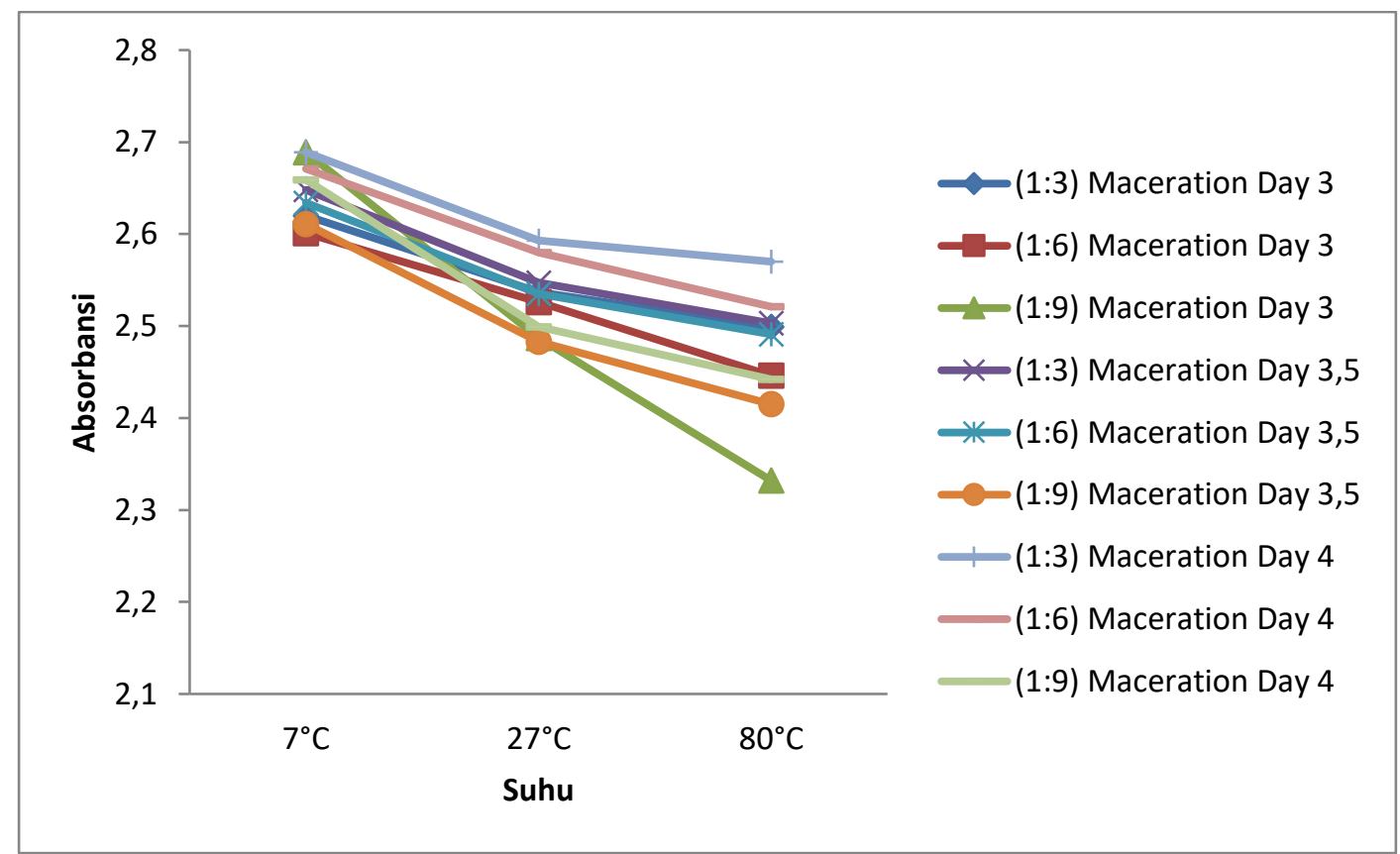

Figure 9. Stability Test of Red Dragon Fruit Skin Extract against Temperature

Based on Figure 9, it can be seen that the higher the temperature, the less the absorbance value obtained. This is due to damage to the pigment chromophore groups which causes discoloration [11]. The decrease in color stability due to the increase in temperature is caused by the decomposition of anthocyanins from the form of aglycones to colorless chalcones. Dragon fruit peel extract stability test is most stable at $7{ }^{\circ} \mathrm{C}$. Based on the analysis of variance, it can be seen that the ratio of $10 \%$ citric acid solvent, maceration time, and the interaction between the two treatments had a very significant effect $(\mathrm{p}<0.01)$. The stability test at $7^{\circ} \mathrm{C}$ can be seen in Table 10 .

Based on Table 10. it can be seen that the treatment ratio of $10 \%$ citric acid solvent (1:3) and 4 days of maceration time produces the highest absorbance value of 2.689. This is also comparable to the highest anthocyanin levels obtained in the same treatment at a solvent ratio of $10 \%$ citric acid (1: 3 ) and 4 days of maceration time (Table 3). The higher the anthocyanin levels in the red dragon fruit peel extract, the more stable the red dragon fruit peel extract is against temperature. 
Table 10

Stability Test at $7{ }^{\circ} \mathrm{C}$

\begin{tabular}{lccc}
\hline Treatment & \multicolumn{3}{c}{ Maceration Time } \\
\hline Solvent & day 3 & day 3.5 & day 4 \\
\hline$(1: 3)$ & $2.620 \mathrm{c}$ & $2.648 \mathrm{~b}$ & $2.689 \mathrm{a}$ \\
& $(\mathrm{a})$ & $(\mathrm{a})$ & $(\mathrm{a})$ \\
$(1: 6)$ & $2.601 \mathrm{c}$ & $2.634 \mathrm{~b}$ & $2.671 \mathrm{a}$ \\
& $(\mathrm{b})$ & $(\mathrm{b})$ & $(\mathrm{b})$ \\
$(1: 9)$ & $2.589 \mathrm{c}$ & $2.611 \mathrm{~b}$ & $2.658 \mathrm{a}$ \\
& (c) & (c) & (c) \\
\hline
\end{tabular}

\section{Conclusion}

Based on the research results, concluded that the best treatment of red dragon fruit peel extraction obtained in a sample comparison of red dragon fruit peel pulp with $10 \%$ citric acid solvent (1: 3) and 4-days of maceration time results in a yield of $22.92 \%$; $\mathrm{pH}$ value of 1.84 ; anthocyanin levels of $52.27 \mathrm{mg} / \mathrm{L}$; $\mathrm{L} *$ color intensity of 16.54 ; color intensity a * of 75.57 ; color intensity $\mathrm{b} *$ is 9.63. The anthocyanin dye stability test is the best obtained at a $\mathrm{pH}$ of 3 and a temperature of $7^{\circ} \mathrm{C}$.

\section{References}

[1] Citramukti, I. (2008). Ekstraksi dan Uji Kualitas Pigmen Antosianin Pada Kulit Buah Naga Merah (Hylocereus costaricensis).(Kajian Masa Simpan Buah dan Penggunaan Jenis Pelarut).Skripsi Jurusan THP Universitas Muhammadiyah Malang. Malang.

[2] Samsudin E. Khoirudin. (2011). Ekstraksi filtrasi membran dan uji stabilitas zat warna dari kulit manggis (Garcinia mangostana). Skripsi. Fakultas Teknik, Universitas Diponegoro. www.eprints.undip.ac.id.

[3] Tensiska, E. (2006). Ekstraksi Pewarna Alami dari Buah Arben (Rubus idaeus (Linn.)) dan Aplikasinya pada Sistem Pangan. http://digilib.umm.ac.id.

[4] Simanjuntak, L. Chairina, dan S. Fatimah. (2014). "Ekstraksi Pigmen Antosianin Dari Kulit Buah Naga Merah (Hylocereus polyrhizus)". Jurnal Teknik Kimia USU. 3(2):25-30.

[5] Amanda, A. Kurniaty, I. (2017). Pengaruh Waktu Maserasi Terhadap Rendemen Zat Antosianin Pewarna Alami Minuman Jelly dari Terong Ungu. Fakultas Teknik Universitas Muhammadiyah Jakarta.

[6] Pareira, M. (2008). Pemanfaatan Kulit Buah Manggis untuk Dijadikan Pewarna Alami. http://www.macklin.onbuk.com/2008/12/pemanfaatankulit-buah-manggis-untuk-dijadikan-bahanpewarna-alami/. Diakses pada 17 Agustus 2020.

[7] Wijaya, L. S., S.B. Wijanarko dan T.Susanto. (2001). Ekstraksi dan Karakteristik Pigmen dari Kulit Buah Rambutan (Nephelium lappaceum) var Binjai. Biosain. 1(2):1-16.

[8] Manasika, A. dan Widjanarko, S. M. (2015). Ekstraksi Pigmen Karotenoid Labu Kabocha Menggunakan Metode Ultrasonik (Kajian Rasio Bahan : Pelarut dan Lama Ekstraksi). Jurnal Pangan dan Agroindustri. 3(3):928-938.

[9] Mangku, I. G. P and Rudianta, I. N. (2019). Stabilization of The Quality and Anthocyanin in Strawberry Puree During Storage. Journal of Physics: Conference Series 1402022063 page:1-7.

[10] Hidayah, T. 2013. Uji Stabilitas dan Antioksidan Hasil Ekstraksi Zat Warna Alami dari Kulit Buah Naga (Hylocereus undatus). Skripsi. Universitas Negeri Semarang.

[11] Hidayah, T. Pratjojo, W., dan Widiarti, N. (2014). Uji Stabilitas Pigmen dan Antosianin Ekstrak Zat Warna Alami Kulit Buah Naga Merah. Indonesian Journal of Chemical Science. 3(2):135-140. 